\title{
Winged Accrescent Sepals and their Taxonomic Significance within the Chenopodiaceae: A Review
}

\author{
Gamal E.B. El Ghazali 1
}

\author{
${ }^{1}$ Faculty of Science \& Arts at Alrass, Qassim University, Saudi Arabia
}

\begin{abstract}
The present study aims to review the presence of winged accrescent sepals in various plant families with emphasis to the Subfamilies, Tribes and genera of the Chenopodiaceae and their significance in classification. Winged accrescent sepals were found to be sporadically scattered in 24 dicotyledonous and two monocotyledonous, one Gymnosperm and one Bryophyte families. In the Chenopodiaceae, winged accrescent sepals are present in three Subfamilies, five Tribes and 26 genera. The present review showed that these modified sepals although are unique morphological features in certain genera, Tribes and Subfamilies in the family Chenopodiaceae, they are also encountered in unrelated families and are not supported by molecular characteristics. Within the Chenopodiaceae, both the genera Sarcobatus and Dysphania, possess winged accrescent sepals, but molecular characteristics support the transfer of the genus Sarcobatus to a separate family, and confirmed the position of Dysphania within the family Chenopodiaceae. In addition, based on molecular characteristics, Subfamily Polycnemoideae which doesn't possess winged accrescent sepals, shared similarity with the Chenopodiaceae.
\end{abstract}

Keywords: Modifications of Sepals, Sarcobatus, Dysphania, Polycnemoideae, Molecular Characteristics

\section{Introduction:}

Sepals are usually green and their primary function is the protection of the flowers at the bud stage (Endress, 2001). These sepals may wither and drop off as soon as the flower bud open (Caducous/ fugacious), or fall off after the process of anthesis (deciduous), or remain persistent beyond anthesis. Persistent sepals may appear shriveled (marcescent) or may grow and show further modifications (accrescent) (Saxena, 2010).

Accrescent sepals may show various modifications, which suggest that they are adapted for functions not related to the protection of the flower at the bud stage (Herrera, 2005). Accrescent sepals may be spinescent as in Eremophilia regens (Chinnock, 2007), hooked bristles as in Pectocarpa pulsilla (Beidlemen and Kozloff , 2014), glandular hairs as in Rosmarinus officinalis (Bottega and Corsi, 2000), inflated as in Physalis (Hu and Saedler, 2007), hooded as in Acontium (Jabeen et al. 2013), corky tubercles as in Rumex crispus (Anwar Maun 2009), fleshy as in Hibiscus sabdariffa (Da-Costa-Rocha et al. 2014), petaloid as in Musseanda frondosa (Jayaweera 1963), hairy pappus as in Volutarella divaricata (Naidu, 2012), feathery pappus as in Tridax procumbens (Naidu, 2012), pappus of capillary bristles as in Aster (Larson, 1993), pappus of retrorely barbed awns as in
Bidens (Larson, 1993), pappus of plumose bristles as in Cirsium (Larson, 1993), crowned as in Diabelia landrein (Landrein, 2010), crested as in Iris (Guo, 2015), reflexed collar as in Datura (Radford et al. 1964), foliose as in Boopis (Zavala-Gallo, 2011), scaly as in Helianthus (Larson, 1993), with black glands as in Hypericum montanum (Heenan, 2014), horn-like projections as in Trapa (Les, 2017), spathaceous as in Gluta (Watt, 2014), wart-like projections as in Chenolea convallis (Snijman and Manning, 2013), cowl-shaped as in Chenolea diffusa (Snijman and Manning, 2013), tubercled as in Panderia (Kuhn, 1993), parchment-like as in Anredera (Sperling and Bittrich, 1993) and winged as in various species of the family Chenopodiaceae (Zhu et al. 2003). These winged accrescent sepals are regarded as an adaptation to wind dispersal (Jurado et al. 1991).

The presence of winged accrescent sepals affect various physiological behaviors. They reduce the germination percentage and germination rate (Bhatt et al. 2017), affect germination and mortality (Yu et al. 2009), regulate dormancy and germination behaviour (El Keblawy et al. 2014), inhibit germination by acting as mechanical barrier (Chu et al. 2014), increase germination rate in light higher

This article is published under the terms of the Creative Commons Attribution License 4.0

Author(s) retain the copyright of this article. Publication rights with Alkhaer Publications.

Published at: http://www.ijsciences.com/pub/issue/2018-05/

DOI: 10.18483/ijSci.1650; Online ISSN: 2305-3925; Print ISSN: 2410-4477 
Winged Accrescent Sepals and their Taxonomic Significance within the Chenopodiaceae: A Review

than in darkness (Ma et al. 2016), and protect fruits by secretion (Bottega and Corsi, 2000).

A wide number of characters were used by various authors to describe the winged accrescent sepals. These criteria include: shapes, size, colour, equal/ unequal, place of insertion, number of segments, aestivation, veins +/- prominent, shape of apex, twisted /untwisted, sessile/ stipate, vertical/ horizontal (Amaral and Bittrich 2014, Cabrera et al. 2009, Freitag et al. 2001, Kuhn et al. 1993, Panda and Reveal 2012, Welsh et al. 2003, Sukhorukov and Konstantinov 2012, Wilson, 1984, Zhu et al. 2003). The present study aims to review the presence of winged accrescent sepals in various plant families with emphasis to the family Chenopodiaceae and its significance in classification.

\section{Occurrence of winged accrescent sepals in various families}

Plants with winged accrescent sepals were reported to be widely distributed in various taxa (species/ genera), belonging to diverse families in the Plant Kingdom. Winged accrescent sepals were encountered in Bryophytes (one species), gymnosperms (one species), monocotyledons (two species) and dicotyledons (24 taxa) (Table 1).

These dicotyledonous families belong to various Orders, and only six families (Ancistrocladaceae, Basellaceae, Dysphaniaceae, Nyctaginaceae, Polygonaceae and Sarcobataceae) share a common Order (Caryophyllaceae) with the Chenopodiaceae.

Table 1. Families and species/genera reported to possess winged accrescent sepals.

\begin{tabular}{|c|c|c|c|}
\hline & Family & Species/ Genera & Reference \\
\hline \multicolumn{4}{|c|}{ A. Bryophytes: } \\
\hline 1. & Jungermanniaceae & Jungermannia sphaercarpum & Bosanquet (2010) \\
\hline \multicolumn{4}{|c|}{ B. Gymnospersms: } \\
\hline 2. & Welwitschiaceae & Welwitschia mirabilis & Kubitzki (1990) \\
\hline \multicolumn{4}{|c|}{ C. Monocotyledons: } \\
\hline $3-$ & Ericaceae & Pentapterygium sikkimense & Panda and Reveal (2012) \\
\hline 4. & Restionaceae & Staberoha & Linder and Hardy (2010). \\
\hline \multicolumn{4}{|c|}{ D. Dicotyledons: } \\
\hline $5-$ & Anacardiaceae & Astronium, Loxostylis, Parishia & Pell et al. (2011) \\
\hline 6- & Ancistrocladaceae & Ancistrocladus & Thomas and Gereau (1993) \\
\hline 7- & Balsaminaceae & Impatiens guiqingensis & Guo et al. (2016) \\
\hline 8- & Basellaceae & Andredera & Sperling and Bittrich (1993). \\
\hline 9- & Boraginaceae & Trichodesma & Weigend et al. (2016) \\
\hline $10-$ & Caprifloliaceae & $\begin{array}{l}\text { Abelia } \\
\text { Heptacodium }\end{array}$ & Manchester and Donoghue (1995) \\
\hline $11-$ & Chenopodiaceae & 26 genera & Table 2 \\
\hline $12-$ & Convolvulaceae & Calycobolus, Poraneae & Staples and Austin (2009) \\
\hline \multirow[t]{2}{*}{$13-$} & \multirow[t]{2}{*}{ Dipterocarpaceae } & Shorea & Suzuki and Ashton (1996), Li et al. (2000). \\
\hline & & $\begin{array}{l}\text { Marquesia, Monotes, } \\
\text { Pseudomonotes }\end{array}$ & Maury-Lechon and Curtet (1998) \\
\hline 14- & Dysphaniaceae & Dysphania simulans & Wilson (1984) \\
\hline 15- & Eriocaulaceae & Eriocaulon & Phillips (1997), De Oliveira and Bove (2015) \\
\hline 16- & Flacourtiaceae & Homalium & Mabberley (1997) \\
\hline 17- & Fabaceae & Apoplanesia paniculata & Conrad (2009) \\
\hline \multirow[t]{3}{*}{$18-$} & \multirow[t]{3}{*}{ Gentianaceae } & Sabatia & Taylor (2016) \\
\hline & & Schultesia pachyphylla & Quimaraes et al (2013) \\
\hline & & Exacum & Shahine and Nampy (2016) \\
\hline 19- & Malpighiaceae & Dicella & Davis et al. (2001) \\
\hline \multirow[t]{2}{*}{$20-$} & \multirow[t]{2}{*}{ Malvaceae } & Malvastrum hispidium & Smith (2008) \\
\hline & & Pentaplaris & Bayer and Dorr (1999) \\
\hline $21-$ & Nyctaginaceae & Boerhavia, Phaeoptilum, & Struwig et al. (2015) \\
\hline $22-$ & Ochnaceae & Lophira & Amaral and Bittrich (2104) \\
\hline \multirow[t]{2}{*}{$23-$} & \multirow[t]{2}{*}{ Polygonaceae } & Fallopia japonica & Saldana et al. (2009). \\
\hline & & Reynoutria & Mohlenbrock and Thomson (2009) \\
\hline
\end{tabular}


Winged Accrescent Sepals and their Taxonomic Significance within the Chenopodiaceae: A Review

\begin{tabular}{|l|l|l|l|}
\hline & & Polygonum & Cullen (2001) \\
\cline { 3 - 4 } & & Rumex & Boulos (1999), Larson (1993) \\
\hline $24-$ & Sarcobataceae & Sarcobatus & Hils et al. $(2003)$. \\
\hline $25-$ & Solanaceae & Nicandra physalodes & Hyde et al. (2017) \\
\hline $26-$ & Urticaceae & Pouzolzia floresiana & Wilmot-Dear and Friis (2012). \\
\hline $27-$ & Verbenaceae & Petrea & Jafri and Abdul Ghafoor (1974). \\
\hline $28-$ & Zygophyllaceae & Zygophyllum xanthoxylum & Yu et al. (2009) \\
\hline
\end{tabular}

\section{Occurrence of winged accrescent sepals in the Chenopodiaceae}

Chenopodiaceae was subjected to numerous rearrangements at the order and subfamily levels. At the order level, it was regarded to belong to Centrospermae (Ulbrich, 1934), Caryophyllaceae (Cronquist, 1981, Takhtajan, 1969), and Chenopodiales (Thorne 1992, Hutchinson 1959). Using morphological and anatomical characters, two, three, four and eight subfamilies were recognized by
Meyer (1829), William and Ford-Lloyd (1974), Kuhn et al. (1993) and Ulbrich (1934) respectively. According to recent molecular characters, Chenopodiaceae was divided into seven subfamilies (Kadereit et al. 2003) namely: Chenopodioideae, Salicornioideae, Salsoloideae, Betoideae, Corispermoideae, Suaedoideae and Sclerolaeneae. Within these seven subfamilies, winged sepals were encountered in three Subfamilies and five Tribes (Table 2).

Table 2. Subfamilies, Tribes and genera reported to possess winged accrescent sepals within the Chenopodiaceae.

\begin{tabular}{|c|c|c|c|c|}
\hline & Subfamily & Tribe & Genus & Reference \\
\hline $1-$ & Corisperoideae & Corispermeae & $\begin{array}{l}\text { Agriophyllum } \\
\text { Anthochlamys }\end{array}$ & Sukhorukov and Konstantinov (2012). \\
\hline 2- & Suaedoideae & Biernertieae & Bienertia & Freitag et al. (2001), \\
\hline \multirow[t]{23}{*}{$3-$} & \multirow[t]{23}{*}{ Salsoloideae } & \multirow[t]{7}{*}{ Camphorosmeae } & Bassia & \multirow{7}{*}{$\begin{array}{l}\text { Snijman and Manning (2013), Welsh et al. } \\
\text { (2003), Wilson (1984), Zhu et al. (2003). }\end{array}$} \\
\hline & & & Cycloloma & \\
\hline & & & Kochia & \\
\hline & & & Neokochia & \\
\hline & & & Eokocia & \\
\hline & & & Osteocarpum & \\
\hline & & & Panderia & \\
\hline & & \multirow[t]{4}{*}{ Sclerolaeneae } & Maireana & \multirow[t]{4}{*}{ Wilson (1984). } \\
\hline & & & Didymanthus & \\
\hline & & & Sclerochlamys & \\
\hline & & & Sclerolaena & \\
\hline & & \multirow[t]{12}{*}{ Salsoleae } & Agathophora & \multirow{12}{*}{$\begin{array}{l}\text { Freitag et al. (2001), Welsh et al. (2003), Zhu et } \\
\text { al. (2003). }\end{array}$} \\
\hline & & & Arthrophytum & \\
\hline & & & Anabasis & \\
\hline & & & Girgensohnia & \\
\hline & & & Halogeton & \\
\hline & & & Halothamnus & \\
\hline & & & Haloxylon & \\
\hline & & & Iljinia & \\
\hline & & & Noaea & \\
\hline & & & Salsola & \\
\hline & & & Seidlitzia & \\
\hline & & & Sympegma & \\
\hline
\end{tabular}

\section{Discussion and Conclusions}

Winged accrescent sepals occur in various taxa (species/ genera) belonging to diverse families in the plant Kingdom (Bryophytes, gymnosperms, monocotyledons and dicotyledons), and exist in abundance in the dicotyledons. Within the dicotyledonous families, winged accrescent sepals were prominent in the Chenopodiaceae with 26 genera (Table1). In the Chenopodiaceae, genera with winged accrescent sepals were particularly abundant in Subfamily: Salsoloideae and Tribe: Camphorosmeae. Cabrera et al. (2009), working with 15 morphological characters, showed that the presence of these modified sepals coincide with molecular characters in supporting the close affinity between various members of Tribe Camphorosmeae. 
The use of winged accrescent sepals as morphological charters doesn't always support molecular characteristics in the classification of the Chenopodiaceae.

The genus Sarcobatus was traditionally classified in the Chenopodiaceae based on morphological characters (Abrams and Ferris, 1944). However, based on sieve-tube plastids (Behnke, 1997), plastids (Downie et al. 1977), and supported by DNA analysis (Clement and Mabry, 1996), the genus was transferred by Behnke (1977) to family Sarcobataceae, in close proximity to Phytolaccaceae and Nyctaginaceae. winged Accrescent sepals were not reported by Phytolaccaceae, but were encountered in Sarcobatus (Hils et al. 2003), various members of Chenopodiaceae and certain members of Nyctaginaceae (Table 1).

The genus Dysphania was subjected to various treatments, it belongs to Chenopodiaceae by Brown (1810), to Illecebraceae by Hooker (1880), to Caryophyllaceae by $\operatorname{Pax}$ (1889), to a section in Chenopodium by Allen (1930), and to a distinct family, Dysphaniaceae by Pax and Hoffman (1934). Eckhardt (1967) after examining the morphology and development of the flowers of two species of the genus Dysphania, concluded that the genus is related to Chenopodiaceae and does not deserve separate familial status. Recent phytogenetic studies, have confirmed the position of the genus within the Chenopodiaceae (Kadereit et al, 2003).

Polycnemoideae was traditionally treated as a subfamily of the Chenopodiaceae (Kuhn et al. 1993). However, based on molecular studies, Polynemoideae shares similarities with both Amaranthacae and Chenopodiaceae (Kadereit et al. 2003). Unlike many species of Chenopodiacea (Table 2 ), winged accrescent sepals were not encountered in neither Amaranthaceae nor Polycnemoideae.

\section{References}

1. Abrams, L. and Ferris, R.S. (1944). An illustrated flora of the Pacific States: Washinton, Oregon and California, vol. 2. Stanford University Press, Stanford. https://archive.org/illustrated flora02abra.

2. Allen, P. (1930). Die systematische Stellung und Gliederung der R. Brownschen Gattung Dysphania. Botanische Jahrbucher fur Systematik, Pflanzengeschichte und Pflanzengeographie, 63: 483-492.

3. Amaral, M.C.E. and Brittrich, V. (2014). Ochnaceae. In: K. Kubitzki (ed.), The families and genera of vascular plants, vol. XI: Flowering plants- Eudicots, Malpighiales. Springler, Heidelberg. www.worldcat.org/

4. Anwar Maun, M. (2009). The biology of the coastal sand dunes. Oxford University Press, Oxford. https://global.oup.com/academic.

5. Bayer, C. and Dorr, L.J. (1999). A synopsis of the neotropical genus Pentaplaris, with remarks on its systematic position within core Malvales. Brittonia, 51(2): 134-148.

6. https://doi.org/10.2307/2666620, ISSN 0007-196x.
7. Behnke, H.D. (1997). Sarcobataceae- a new family of Caryophyllales. Taxon, 46: 495-507. https://doi.org/10.2307/1224390.

8. Beidleman, L.H. and Kozloff, E.N. (2014). Plants of the San Francisco Bay Region: Mendocino to Monterey. University of California Press Ltd., London. https://www.ucpress.edu/book.php?ISBN9780520278592.

9. Bhatt, A., Phartyl, S. and Nicholas, A. (2017). Ecological role of distinct fruit-wing perianth color in synchronization of seed germination in Haloxylon salicornicum. Plant Species Biology, 32 (2): 121-133. https://doi.org/1.111/1442-1984.12133.

10. Bosanquet, S. (2010). Jungermannia sphaerocarpa. In: Atherton, I., Bosanquet, S. \& Lawley, M. (eds.), Mosses and Liverworts of Britain and Ireland, a field guide. British Bryological Society. http://www.nhbs.com/

11. Bottega, S. and Corsi, G. (2000). Structure, secretion and possible functions of calyx glandular hairs of Rosmarinus officinalis L. (Labiatae). Botanical Journal of the Linnean Society, 132: 325-335.

https://doi.org/10.1111/j.1095-8339.2000.tb01215x.

12. Boulos, L. (1999). Flora of Egypt, vol. one (AzollaceaeOxalidaceae). Al Hadara Publishing, Cairo, Egypt. https://doi.org/10.111/j.1756-1051.1999.tb01119.x

13. Brown, R. (1810). Prodromus florae Novae Hollandiae et Insulae Van- Diemen. Richard Taylor, London. https://www.biodiversitylibray.org/bibliography/3678.

14. Cabrera, J.F., Jacobs, S.W.L. and Kadereit, G. (2009). Phylogeny of the Australian Camphorosmeae (Chenopodiaceae) and the taxonomic significance of the fruiting perianth. International Journal of Plant Sciences, 170(4): 505-521. https://doi.org/10.1086/597267.

15. Chinnock, R.J. (2007). Eremophila and allied genera: a Monograph of the plant family Myoporaceae. Rosenberg Publishing Ltd., New South Wales. https://trove.nla.au/version/46539351.

16. Chu, G., Wang, M. and Zhang, S. (2014). Factors influencing seed germination of medicinal plant Anabasis aphylla L. in salt desert of Xinjiang, China. International Journal of Plant Research, 27(1): 123-129. https://doi.org/10.5958/j.22294473.1.020.

17. Clement, J.S. and Mabry, T.J. (1996). Pigment evolution in the Caryophyllales: a systematic overview. Botanica Acta, 109:360-367. https://doi.org/10.1111/j.1438-8677.1996.tb00584.x

18. Cronquist, A. (1981). An integrated system of classification of flowering plants. Columbia University Press, New York. https://trove.nla.gov.au/version/45201591

19. Cullen, J. (2001). Handbook of North European Garden plants: with keys to families and genera. Cambridge University Press, Cambridge. www.cambridge.org/vi/search?query $=9780521004114$

20. Da-Costa-Rocha, I, Bonnlaender, B., Sievers, H., Pischel, I. and Heinrich, M. (2014). Hibiscus sabdariffa L. - A phytochemical and pharmacological review. Food Chemistry, 165: https://doi.org/10.1016/j.foodchem.2014.05.002

21. Davis, C.C., Anderson, W.R. and Donoghue, M.J. (2001). Phylogeny of Malpighiaceae: evidence from chloroplast NDHF and TRNL- F nucleotide sequences. America Journal of Botany, 88(10): 1830-1846. https://www.ncbi.nlm.nih.gov/pubmed/21669617

22. De Oliveira, A.L. R., and Bove, C.P. (2015). Eriocaulon L. from Brazil: An Annotated checklist and taxonomic novelties. Acta Botanica Brasilica, 29(2): 175-189. https://dx.doi.org/10.1590/0102-33062014abb3668.

23. Downie, S.R., Ratz-Downie, D.S. and Cho, K.J. (1977) Retationships in the Caryophyllaceae as suggested by phylogenetic analysis of partial chloroplast DNA ORF 2280 homolog sequence. American Journal of Botany, 84: 253273. http://experts.illimos.edu/

24. Eckhardt, T. (1967). Vergleich von Dysphania mit Chenopodium und mit Illecebraceae. Bauhinia, 3: 327-344. 
25. El-Keblawy, A.A., Bhatt, A. and Gairola, S. (2014). Perianth colour affects germination behaviour in wind-pollinated Salsola rubescens in Arabian deserts. Botany, 92: 69-75. https://doi.org/10.1139/cjb-2013-0183

26. Endress, P.K. (2001). Origins of flower morphology. Journal of Experimental Zoology, 291: 105-115. https://doi.org/10.1002/jez.1063.

27. Freitag, H., Hedge, I.C., Jafri, S.M.H., Kothe-Heinrich, Omer, S. and Uotila, P. (2001). Chenopodiaceae. In: S.I. Ali \& M. Qaiser (eds.), Flora of Pakistan, 204: 178-183. Missouri Botancal Garden Press. www.eflora.org/florataxon.aspx?flora_id=5\&taxon_id=1018 5

28. Guitian, J. and Larrinaga, A.R. (2014). The role of post-floral persistent perianth in Helleborus viridis subsp. occidentalis (Ranunculaceae). Nordic Journal of Botany, 32: 852-857. https://doi.org/10.111/njb.00523.

29. Guo, J. (2015). Comparative micromorphology and anatomy of crested sepals in Iris (Iridaceae). International Journal of Plant Sciences, 176(7): 627-642. https://doi.org/10.1086/682135.

30. Guo, H., Zhang, C., Zhang, L. and Yu, S.X. (2016). Impatiens guiqingensis (Balsaminaceae), a new species from Gansu, China. Phytotaxa 247(3):229-233. https://dx.doi.org/10.11646/phytotaxa.247.3.6

31. Heenan, P.B. (2014). Hypericaceae. In: Breitwieser, I., Brownsey, P.J., Heenan, P.B. \& Wilton, A.D. (eds.), Flora of New Zealand - Seed Plants. Fascicle 1. Manaaki Whenua Press, Lincoln. https://doi.org/10.7931/j2mw2f2b.

32. Herrera, C.M. (2005). Post-floral perianth functionality: contribution of persistent sepals to seed development in Helleborus foetidus (Ranunculaceae). American Journal of Botany 92(9): 1486-1491. https://doi.1D.3732/ajb.92.9.1485.

33. Hils, M.H., Thieret, J.W. and Morefield, J.D. (2003). Sarcobatus Nees. In: S.L. Welsh, C.W. Crompton \& S.E. Clements (eds.), Flora of North America. 4: 387-389, Oxford University http://www.eloras.org/florataxon.aspx?flora

34. Hooker, J,D. (1880). Chenopodiaceae. In: Benthan, G. \& Hooker, J.D. (eds.), Genera Plantarum, Vol 3. Reeve \& Co., London.

35. Hu, J.Y. and Saedler, H. (2007). Evolution of the inflated calyx syndrome in Solanaceae. Molecular Biology and Evolution, 24(11): 2443-53. https://doi.org/101093/mo/bev/msm177.

36. Hutchinson, J. (1959). The families of flowering plants. Oxford University Press.

37. Hyde, M.A., Wurstem, B.T., Ballings, P. and Palgrave, C. (2017). Flora of Zimbabwe: species Information: Nicandra physalodes.

http://www.zimbabweflora.co.zw/species.php?species_id=15 0440 .

38. Jabeen, N., Kozgar, M.I., Dar, G.H., Shawl, A.S. and Khan, S. (2013). Distribution and taxonomy of genus Aconitum in Kashmir: Potent medicinal resources of Himalayan Valley. Chiang Mai Journal of Science, 40 (2): 173-186. http://itscience.cmu.ac.th/ejournal/

39. Jayaweera, D.M.A. (1963). The Rubiaceous genus Mussaenda: The morphology of the Asiatic species. Arnold Arboretum of Harvard University, 44(1): 111-126. http://www.jstor.org/stable/43781456.

40. Jafri, S.M.H. and Abdul Ghafoor (1974). Verbenaceae. In: E. Nair \& S.I. Ali Eds.), Flora of West Pakistan, 77: 1-40. University of Karachi, Karachi. https://trove.nla.gov.au/version/28066374.

41. Jurado, E., Westoby, M. and Nelson, D. (1991). Diaspore weight, dispersal, growth form and perenniality of Central Australian Plants. Journal of Ecology, 79(3): 811-828. http://www.jstor.org/stable/2260669.

42. Kadereit, G., Borsch, T., Weising, K. and Freitag, H. (2003) Phylogeny of Amaranthacaea and Chenopodiaceae and the evolution of C4 photosynthesis. International Journal of Plant Science, 164(6): 959-986. http://www.jstor.org/stable/10.1086/378649.

43. Kubitzki, K. (1990). Welwitchiaceae. In : Kramer, \& Green, P.S. (eds.), The Families and genera of vascular plants, vol. 1, Pteridophytes and Gymnosperms. Springer- Verlg Berlin Heidelberg.

44. Kuhn, U., Bittrich, V., Carolin, R., Freitag, H., Hedge, I.C. Uotila, P. and Wilson, P.G. (1993). Chenopodiaceae. In: Kubitzki, K., Rohwer, J.G. \& Bittrich, V. (eds.), The families and genera of vascular plants 2. Springer-Verlag Berlin, Heidelberg.

45. Landrein, S. (2010). Diabelia: a new genus of tribe Linnaeeae subtribe Linnaeinae (Caprifoliaceae). Phytotaxa, 3: 34-38. www.mapress.com/phytotaxon/content/2010/f/p00003p038f

46. Larson, G.E. (1993). Aquatic and wetland vascular plants of the Northern Great plains. United States Department of Agriculture, Forest Service. General Technical Report, RM238, Fort Collins, Colorado. https://www.fs.fed.us/rm/pubs_rm_gtr-238.

47. Les, D.H. (2017). Aquatic dicotyledons of North America: Ecology, life history and systematics. CRC Press. https://www.crcpress.com/

48. Li, X., Li, J. and Ashton, P.S. (2000). Dipterocarpaceae. In: Wu, Z., Peter, H.R., Hong, D. (eds.). Flora of China, 13: 4854, Missouri Botanical Garden., St. Louis

49. Linder, H.P. and Hardy, C.R. (2010). A generic classification of the Restioneae (Restionaceae), Southern Africa. Bothalia 40 (1): 1-35. https://doi.org/10.4102/abc.v40i1.178.

50. Ma, Y., Zhang, J., Li, X., Zhang, S. and Lan, H. (2016). Effect of environmental stress on seed germination and seedling growth of Salsola ferganica (Chenopodiaceae). Acta Ecologica $\quad$ Sinica, 36(6): 456-463. https://doi.org/10.1016/j.chnaes.2016.09.008.

51. Meyer, C.A. (1829). Chenopodiaceae. In: Ledebour, C.F (ed.). Flora Altaica, Berlin, Reimer.

52. Manchester, S.R. and Donoghue, M.J. (1995).Winged fruits of Linnaeeae (Caprifoliaceae) in the Tertiary of Western North America: Diplodipelta Gen. Nov. International Journal of Plant Science, 156(5): 709-722. https://www.journals.uchicago.edu/doi/abs/10.1086/297293.

53. Mabberley, D.J. (1997). The plant-book, a portable dictionary of the vascular plants. Cambridge University Press. https://cambridge/org/core/books/

54. Maury-Lechon, G. and Curtet, L. (1998). Biogeography and evolutionary systematics of Dipterocarpaceae. In: S Appanah and J. M. Turnbull (eds.), A review of Dipterocarps: taxonomy, ecology and silviculture. Centre for International Forestry Research, Malaysia.

55. Mohlenbrock, R.H. and Thomson, P.M. (2009). The illustrated flora of Illinois, Flowering pants: smart weeds to Hazel nuts. South Illinois University Press. https://nhbs/com/series.

56. Naidu, V.S.G.R. (2012). Hand Book on weed identification. Directorate of Weed Science Research, Jabalpur, India. https://www.scribd.com/document/343883722/

57. Panda, S. and Reveal, J.L. (2012). A step- two lectotypification and epitypification of Pentapterygium sikkimense W.W. Sm. (Ericaceae) with an amplified description. Phytoneuron, 8: 1-7. http://www.phytoneuron.net/phyton-pentapterygium.

58. Pax, F.A. (1889). Dyshania. In: Engler, A. \& Prantl, K (eds.). Die naturlichen Pflanzen familien, 3(1b):92. Verlag von Wilhelm Englemann, Leipzig.

59. Pax, F.A. and Hoffman, K. (1934). Dysphaniaceae. In: In: Engler, A. \& Harms, H. (eds.). Die naturlichen Pflanzen familien, 16c:272-274. Duncker \& Hunbolt, Berlin.

60. Pell, S.K., Mitchell, J.D., Miller, A.J. and Lobova, T.A. (2011). Anacardiaceae. In: K. Kubitzki (ed.), The families and genera of vascular plants, vol. 10: Flowering plants, Eudicots. Springer-Verlag Berlin, Heidelberg.

61. Phillips, S. (1997). Eriocaulaceae, In: R.M. Polhill (ed.), Flora of Tropical East Africa. A.A. Balkema, Rotterdam.

62. Quimaraes, E.F., Dalvi, V.C., and Azevedo, A.A. (2013). Morphoanatomy of Schultesia pachypylla (Gentianaceae): a 
discordant pattern in the genus. Botany, 91(12): 830-839. https://doi.org/10.1139/cjb-2013-0077.

63. Radfort, A., Ahles, H.E. and Bell, C.R. (1964). Manual of the vascular Flora of the Carolinas. The University of North Carolina Press. https://www.amzon.com/

64. Saldana, A., Fuentes, N. and Pfanzelt, S. (2009). Fallopia japonica (Houtt.) Ronse Decr. (Polygonaceae: a new record for the alien Flora of Chile. Gayana Botanica 66(2): 283-285. http://dx.doi.org/10.4067/s0717-66432009000200014.

65. Saxena, N.P. (2010). Objective Botany. Krishna Prakasnan Media, Ltd, India. https://www.bookdepository.com/objective_botany-N-PSaxena.

66. Shahina, P.M. and Nampy, S. (2016). A taxonomic revision of Exacum L. (Gentianaceae- Exaceae) in South India. International Journal of Advanced Research, 4(3): 16531683. http://www.journalijar.com.

67. Smith, T.E. (2008). Current status of yellow false Mallow (Malvastrum hispidium) in Mossouri. Missouriensis, 28/29: 5- $9 . \quad$ https://monativeplants.org/wpconent/uploads/missouriensis-2829.

68. Snijman, D.A. and Manning, J.C. (2013). Chenopodiaceae. Chenolea convallis, a new species from western Cape Province, South Africa. Bothalia (African Biodiversity and Conservation), 43(1): 80-84. https://doi.org/10.4102/abc.v43i1.111.

69. Sperling, C.R. and Bittrich, V. (1993). Basellaceae. In: Kubitzki, K., J.G. Rohwer \& V. Bittrich (eds.). Flowering plants, Dicotyledons. Springer-Verlag, Berlin Heidelberg. http://www.springer.com/la/book/9783540555094.

70. Staples, G.W. and Austin, D.F. (2009). Revision of Neotropical Calycobolus and Porana (Convolvulaceae). Edinbrugh Journal of Botany, 66(1): 133-153. https://doi.org/10.1017/s0960428609005319.

71. Struwig, M., Klaassen, E.S. and Kwembey, E.G. (2015). Nyctaginaceae: a taxonomic treatment for the Flora of Namibia. $\quad$ Phytotaxa, 238(2): 101-135. http://dx.doi.org/1011646/phytotaxa238.2.1

72. Sukhorukov, A.P. and Konstantinova (2012). Fruit anatomy of Anthochlams (Chenopodiaceae/ Amaranthaceae). In: Timonin, A.K., Sukhorukov, A.P., Harper, G.H. and Nilova, M.V. (eds.), Caryophyllaceae: New insights into the phylogeny, systematics and morphological evolution of the Order. Lomonosov State University, Moscow, 24-27 Sept.

73. Suzuki, S. and Ashton, P.S. (1996). Sepal and nut size ratio of fruits of Asian Dipterocarpaceae and its implications for dispersal. Journal of Tropical Ecology, 12(6): 853-870. https://doi.org/10.1017/s0266467400010129.

74. Takhtajan, A. (1969). Flowering plants. Origin and dispersal. Oliver and Boyd, Edinburge.
75. Taylor, E. (2016). Pollination ecology of Sabatia campestris Nutt (Gentianaceae). Oklahoma Native Plant Record, 16: 4-9. https://creativecommons.org/licenses/by-nc-sa/4.0/legalcode.

76. Thomas, D.W. and Gereau, R. (1993). Ancistrocladus korupensis (Ancistrocladaceae): A new species of Liana from Cameroon. Novon: A Journal for Botanical Nomenclature, 3(4): 494. https://doi.org/10.2307/3391401.

77. Thorne, R.F. (1992). An updated phylogenetic classification of the flowering plants. Aliso: A Journal of Systematic and

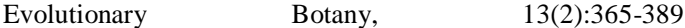
https://doi.org/10.5642/aliso.19921302.08.

78. Watt, G. (2014). A dictionary of the economic products of India, volume 1: Abaca to Buxus. Cambridge University Press. www.cambridge.org/coretittle/gb/450597.

79. Weigend, M., Selvi, F. Thomas, D.C. and Hilget, H.H (2016). Boraginaceae. In: Kadereit, J.W. \& Bittrich (eds.). The families and genera of vascular Plants, vol. 14, Flowering Plants. Cham: Springer- International Publishing. www.springer.com/

80. Welsh, S.L., Crompton, C.W. and Clemants, S.E. (2003). Chenopodiaceae. In: Editorial Committee (ed.), Flora of North America, 4: 258-404 https://www.efloras.org/florataxon.aspx.

81. Wilson, P.G. (1984). Chenopodiaceae. In: A.S. George (ed.) Flora of Australia 4, Phytolaccaceae to Chenopodiaceae. Commonwealth of Australia, Canberra https:www.environment.gov.au/

82. William, T.T. and Ford-Lloyd, B.V. (1974). The systematics of the Chenopodiaceae. Taxon, 23(2-3): 353-354. http://www.jstor.org/stable/i252271.

83. Wilmot-Dear, C.M. and Friis, I. (2012). Pouzolzia floresiana (Urticaceae), a new species from Flores, Nusa Tenggara Timur (Lesser Suda Islands), Indonesia. Edinburgh Journal of $\begin{array}{llll}\text { Botany, } & 69 & \text { (2): } & \text { 293-299. }\end{array}$ https://doi.org/10.1017/s0960428612000121.

84. Ulbrich, E. (1934). Chenopodiaceae. In: Engler, A. \& Prantl, K. (eds.). Die natu rlichen Planzenfamilien, vol. $16 \mathrm{c}$. Engelmann, Leipzig.

85. Yu, J., Hu, X., Wang, Y., Yang, L., and Zhang, B. (2009). Effects of winged perianth and its water extracts of Zygophyllum xanthoxylum on seed germination. Acta Botanica Boreali-Occidentalia Sinica, 29(4): 795-799. www.cnki.com.cn.

86. Zavala-Gallo, L., Denham, S.S. and Pozner, P. (2011). Two new species of Boopis (Calyceraceae) from Argentina. $\begin{array}{ll}\text { Brittonia, 3(1): 113-117. } & \end{array}$ http://www.jstor.org/stable/41406769.

87. Zhu, G., Mosyakin, S.L. and Clements, S.E. (2003) Chenopodiaceae. In: W. Zhengyi \& P.H. Raven (eds.), Flora of China, 5: 351-414. Missouri Botanical Garden Press. www.eFloras.or/florataxon. 